\title{
Temperature resistance of Hesiolyra bergi, a polychaetous annelid living on deep-sea vent smoker walls
}

\author{
Bruce Shillito $^{1, *}$, Didier Jollivet ${ }^{2}$, Pierre-Marie Sarradin ${ }^{3}$, Philippe Rodier ${ }^{3}$, \\ François Lallier ${ }^{2}$, Daniel Desbruyères ${ }^{3}$, Françoise Gaill ${ }^{1}$
}

\author{
${ }^{1}$ Unité Mixte de Recherche 7622 (UMR), Centre National de la Recherche Scientifique (CNRS), Laboratoire de Biologie \\ Moleculaire et Cellulaire du Developpement (LBMCD), Marine Biology Group, University of Paris (UPMC), 7 Quai St Bernard, \\ Batiment A, 75252 Paris Cedex 5, France \\ ${ }^{2}$ Roscoff Marine Station, Unité Propre de Recherche (UPR) 9042, Centre National de la Recherche Scientifique (CNRS), \\ Ecophysiology Group, BP 74, 29682 Roscoff Cedex, France \\ ${ }^{3}$ Institut Français de Recherche Pour l'Exploitation de la Mer (IFREMER) Centre de Brest, DRO-EP, BP 70, 29280 Plouzané, France
}

\begin{abstract}
For the first time, in vivo heat-exposure experiments were conducted on the hydrothermal vent polychaete Hesiolyra bergi from the hottest part of the vent biotope. Using a pressurised incubator equipped with video-facilities, we found that $H$. bergi, which forages around and in the tubes of the thermophilic Alvinella sp., became hyperactive once temperature exceeded $35^{\circ} \mathrm{C}$ and further lost co-ordination in the 41 to $46^{\circ} \mathrm{C}$ interval, just before death occurred. Another exposure experiment at $39^{\circ} \mathrm{C}$ for 3 to $4 \mathrm{~h}$ led to $80 \%$ mortality (max) $9 \mathrm{~h}$ after heat shock, and $100 \%$ thereafter. In view of the much higher temperatures recorded in this organism's habitat, these results suggest that tolerance to high temperatures (exceeding $40^{\circ} \mathrm{C}$ ) is not a pre-requisite for life amongst alvinellid tubes. Behavioural responses (escape from heat) may suffice.
\end{abstract}

KEY WORDS: Hydrothermal vents · Behaviour · Adaptation to heat · IPOCAMP Resale or republication not permitted without written consent of the publisher

\section{INTRODUCTION}

Over the last decade, spectacularly high temperature measurements at the East Pacific Rise (EPR) hydrothermal vents have suggested that some invertebrates living on vent chimney walls could experience habitat temperatures far beyond the upper limits usual for sustained survival of most biota. One specimen of the polychaetous annelid Alvinella pompejana was observed curling around a temperature probe indicating $105^{\circ} \mathrm{C}$, while 6 other discrete recordings inside these annelids' tubes indicated values in the 40 to $80^{\circ} \mathrm{C}$ range (Chevaldonné et al. 1992). These observations showed that vent creatures could survive exposure, at least briefly, to very high temperatures. However, a more recent study based on 6 independent time-series temperature

*E-mail: bruce.shillito@snv.jussieu.fr measurements, again inside the tubes of these worms, increased the thermal tolerance limits of this biota: these recordings suggested that $A$. pompejana may survive temperatures of up to $60^{\circ} \mathrm{C}$ for several hours (Cary et al. 1998). In comparison, the ostracod Potamocypris sp., which occurs in hot springs of North America, showed $100 \%$ survival after $5 \mathrm{~h}$ at $49^{\circ} \mathrm{C}$, but only $33 \%$ after $12 \mathrm{~h}$ (Wickstrom \& Castenholz 1973). Therefore, for this organism, considered one of the most thermotolerant aquatic organisms by Chevaldonné et al. (2000), prolonged survival is not possible above $49^{\circ} \mathrm{C}$. Such data inevitably pose the question of temperature tolerance of these 'hot pole' hydrothermal vent species (Fisher 1998, Chevaldonné et al. 2000), especially since biochemical data (Somero 1992) suggest that these same thermophilic species may not survive prolonged exposure to temperatures above 40 to $50^{\circ} \mathrm{C}$ (Dahlhoff \& Somero 1991, Dahlhoff et al. 1991, Childress \& Fisher 
1992, Gaill et al. 1995, Jollivet et al. 1995, Juniper \& Martineu 1995, Desbruyères et al. 1998). Clarification would require in situ recordings of the body temperature of these hot-environment species, a difficult prospect at deep-sea vents (Desbruyères et al. 1998, Fisher 1998). An alternative approach is heat-resistance experiments with live animals in simulated environmental conditions. Provided that animals survive the collection trauma and that appropriate means of evaluating their condition (physiological, behavioural) are available, the question of the temperature resistance of vent animals may be directly addressed by submitting them to various temperature regimes.

Here we present data based on video-observations of vent worms incubated at in situ pressure, using a newly designed pressurized incubator: IPOCAMP (Incubateur Pressurisé pour l'Observation et la Culture d'Organismes Marins Profonds; see Fig. 1a). For the first time, heat-resistance investigations have been carried out on live invertebrates endemic to the hottest part of the hydrothermal vent biotope: the wall of active vent chimneys. Hesiolyra bergi, the 'caterpillar worm' (Blake 1985, Desbruyères et al. 1985, 1998), is an EPR-vent polychaete annelid (Desbruyères \& Segonzac 1997), that attains a maximum length of 6 to $7 \mathrm{~cm}$ (see Fig. 1b). Like other members of the hesionid polychaete family, which live commensally with other polychaetes, crustaceans, sipunculans or echinoderms, $H$. bergi is associated with the thermophilic annelids Alvinella spp., (i.e. A. condota and A. pompejana, the 'pompeii worm'). It frequently visits tubes of Alvinella spp. for short periods (few minutes) until ejection by the occupant worm (see Fig. 2) (Desbruyères et al. 1998). $H$. bergi is believed to graze on bacteria and/or predate the small macrofauna associated with the alvinellid tubes, and is therefore likely to encounter temperatures in the same range as those reported for the habitat of Alvinella species (Desbruyères et al. 1982, Chevaldonné et al. 1991, 1992, Cary et al. 1998, Sarradin et al. 1998). By examining the behaviour and survival of $H$. bergi as a function of temperature, we attemped to determine if its survival in the heat of a smoker wall is a matter of biochemical adaptation, in which case it would survive and remain unaffected at sustained high temperature in the 50 to $60^{\circ} \mathrm{C}$ range, as reported in situ by Cary et al. (1998) for A. pompejana. Alternatively, attempts to escape the heat, followed by death at lower temperatures would indicate an important role of behavioural responses.

\section{MATERIALS AND METHODS}

In situ video-observations. During Dive 1382 (of the submersible 'Nautile' during the French cruise 'HOPE
99' [NO 'Atalante']), almost $1 \mathrm{~h}$ of continuous recording was obtained over several areas of an alvinellid assemblage on a smoker wall (Marker PP 55, $12^{\circ} 49.844^{\prime} \mathrm{N}, 103^{\circ} 56.812^{\prime} \mathrm{W}$ ). During recording, care was taken to maintain the imaging-frame on a given part of the tube masses, in order to document the behaviour of the species living there (Alvinella spp. and other polychaetes, amphipods and peltospirid gastropods). Imaging magnification was as in Fig. 2, sufficient to allow good identification, at the species level, of small fauna such as Hesiolyra bergi.

Pressurised incubator IPOCAMPTM. (Autoclave France). The stainless steel vessel (pv) had a volume of ca $19 \mathrm{l}$. The general design of the pressure circuit was inspired by the flow-through pressure systems used by Quetin \& Childress (1980), with flow rates that reached $20 \mathrm{l} \mathrm{h}^{-1}$ at 260 bar working pressure. Pressure oscillations arising from pump strokes (100 rpm) were less than 1 bar at working pressure. The temperature of the flowing seawater (through a $0.4 \mu \mathrm{m}$ filter) was measured constantly, at pressure, in the inlet and outlet lines $\left( \pm 1^{\circ} \mathrm{C}\right)$. Temperature regulation was powered by a regulation unit (Huber CC 240) that circulated ethylene-glycol through steel jackets surrounding the pv and through the seawater inlet line. IPOCAMP allowed video-observations of the re-pressurized organisms by combining an endoscope (Fort) to a CCD (charge-coupled device) colour camera (JVC, TK-C1380) (Fig. 1). The results were displayed on a TV monitor (JVC), and recorded (Sony SVO-9500 MDP videotape-recorder).

Sample collection and experiments. Hesiolyra bergi specimens were collected from the East Pacific Rise in the $13^{\circ} \mathrm{N}$ hydrothermal vent field at about $2600 \mathrm{~m}$ depth. Collection was achieved with the submersible's hydraulic arm, by 'claw-grabbing' among alvinellid colonies. The animals thus sampled were placed in the temperature-insulated basket of the submersible. Aboard the NO 'Atalante' they were transferred to a $14^{\circ} \mathrm{C}$ cold-room, and $H$. bergi specimens were sorted from amongst the alvinellid tubes and placed in nylonmeshed cages inside the pv (Fig. 1) at an initial seawater temperature of $15^{\circ} \mathrm{C}$. The cages were closed with a transparent polyethylene lid, secured by nylon line. Upon introduction of the worms, the temperature rose by 1 to $2^{\circ} \mathrm{C}$ (see temperature curves in Fig. 3a,b), before being cooled to $15^{\circ} \mathrm{C}$ by temperature-regulating settings. To achieve accurate temperature measurements, an autonomous probe (MICREL instruments, $\pm 0.2^{\circ} \mathrm{C}$ ) was placed next to the cages. Re-pressurization at 260 bar was achieved in about $2 \mathrm{~min}$. In all experiments (corresponding to 4 different collection dives), less than $2 \mathrm{~h}$ intervened between the time the samples commenced decompression (submersible ascent) and the moment they were re-pressurized. 

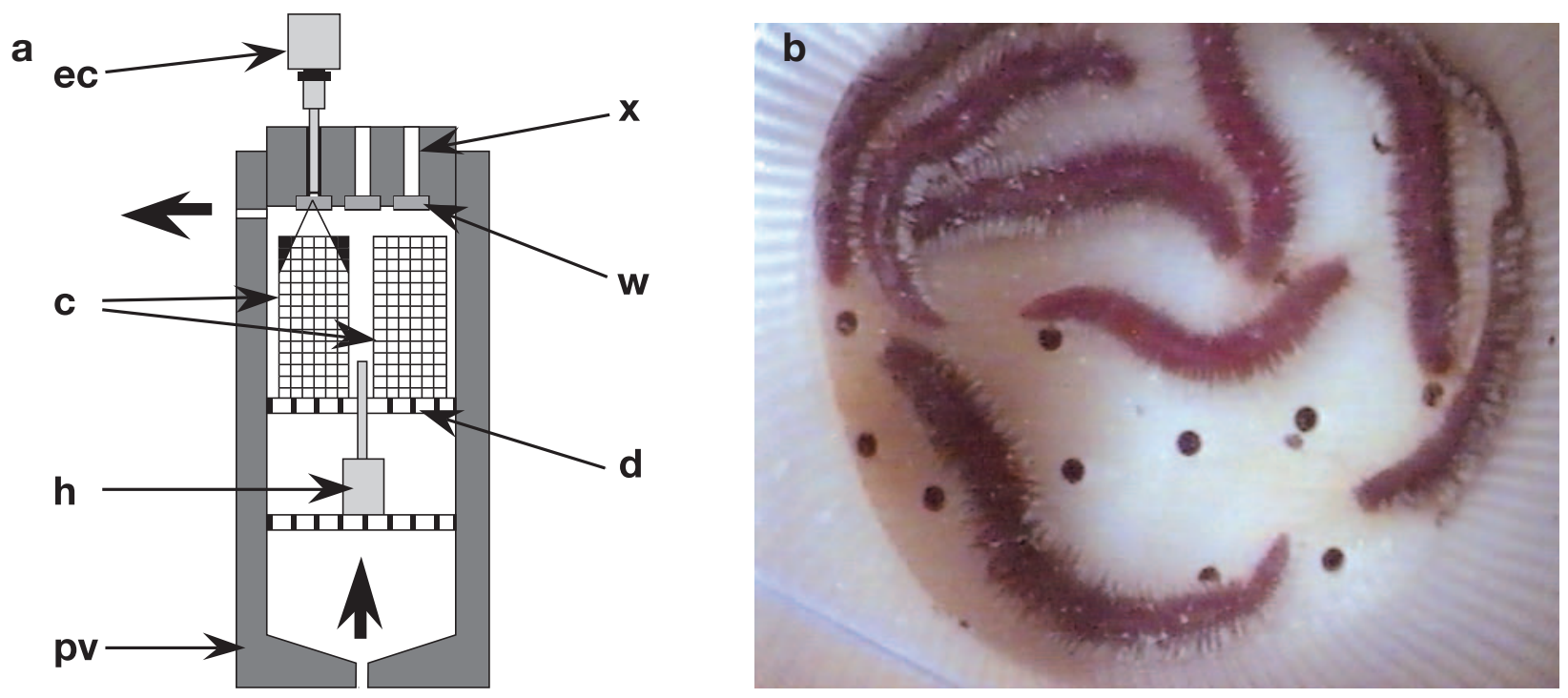

Fig. 1. Experimental set-up for heat-exposure experiments. (a) Pressure vessel (pv) contains 2 cages (c) resting on a plastic support (d). Each cage is a cylinder $(6 \mathrm{~cm}$ diam, $16 \mathrm{~cm}$ height) composed of $1 \mathrm{~mm}$-mesh plankton net, closed at the top with a transparent polyethylene lid. Extremity of an autonomous temperature probe $(\mathrm{h})$ is located between the cages, about $5 \mathrm{~cm}$ above ' $\mathrm{d}$ ', and about $2 \mathrm{~cm}$ away from the cage walls. Three connections (x) in the lid of the pressure vessel are terminated by sapphire windows (w). By inserting an endoscope (ec) into the appropriate connection, content of 1 of the cages may be observed; field of view is such that the edges of the top of the cage are not visible (dark areas). Illumination is achieved through the other 2 connections by means of optical-fibre light-guides. Large arrows indicate inlet and outlet of circulating seawater. (Scale: internal diameter of $\mathrm{pv}=20 \mathrm{~cm}$, height $=\sim 60 \mathrm{~cm}$ ). (b) Video-view of nylon-meshed cage containing 8 Hesiolyra bergi specimens, maintained in the IPOCAMP at in situ pressure (260 bar) and temperature of $15^{\circ} \mathrm{C}$. Parapods of these worms are visible, and appear whitish due to the presence of associated bacteria (scale: diameter of cage bottom $=\sim 6 \mathrm{~cm}$, length of worm in centre $=\sim 3 \mathrm{~cm}$ )

The 4 experiments at in situ pressure were of 2 main types: (1) maintenance at $15^{\circ} \mathrm{C}(2$ experiments, numbered 1, 2, representing a total of 20 individuals) to verify whether the worms recovered from the collection trauma ('control' experiment); (2) heat exposure after $2 \mathrm{~h}$ wait at $15^{\circ} \mathrm{C}$ ( 2 experiments, numbered 3, 4, representing a total of 30 individuals).

Expt 1: Eight worms were placed in 1 cage to study behaviour and survival. In addition, 5 more individuals were placed in sealed containers to evaluate oxygen consumption (these 5 latter worms could not be observed during the experiment).

Expt 2: To reach a total of 15 worms for the survival study at $15^{\circ} \mathrm{C}, 7$ more worms were placed in 1 cage to study behaviour and survival.

In these control experiments, pressure was released for about $15 \mathrm{~min}$ (about 2 bar s$^{-1}$ decompression rate), $6 \mathrm{~h}$ after beginning the experiment to allow retrieval of the 5 individuals (Expt 1: oxygen consumption), and of other organisms (Expt 2) that had also been kept in sealed containers in the pv, for other experimental purposes.

Expt 3: Fifteen individuals were placed in the pv in 2 cages ( 7 and 8 individuals, Fig. 1b) and heat-exposed after $2 \mathrm{~h}$ at $15^{\circ} \mathrm{C}$ until the temperature reached $50^{\circ} \mathrm{C}$, followed by cooling to the original $15^{\circ} \mathrm{C}$.

Expt 4: Having estimated from Expt 3 that the maximum tolerable temperature was above $40^{\circ} \mathrm{C}$, we re- peated the heat-exposure experiment (15 individuals in 2 cages: 7 and 8 individuals, respectively), this time to a temperature of $39^{\circ} \mathrm{C}$, i.e. below the previous estimation. Cooling back to the original $15^{\circ} \mathrm{C}$ took place $6.5 \mathrm{~h}$ after the initial heating.

For the heat-exposure experiments (Expts 3 and 4), observations were recorded over 3 periods: during the first minutes after re-pressurization; during the heating and subsequent cooling periods; at the end of the $18 \mathrm{~h}$ period. As for the controls, this procedure allowed to us determine survival at in situ pressure after $18 \mathrm{~h}$, and to study the worms' behaviour during the periods of temperature variation (see Fig. 3).

Survival after $18 \mathrm{~h}$ (all experiments). Survival of the re-pressurized worms was determined during the final minutes of the pressure experiments, by identifying each individual and witnessing its movements.

Behaviour of worms during heat-exposure vs control experiments (Expts 1, 3, and 4: see Fig. 3). Worms were individually followed during periods of $30 \mathrm{~s}$ at different times during the experiments. Within each period, they were classified into 4 categories:

(1) Motionless, no movement detected at normal tape-reading speed; this category was also applied when an individual's movement seemed to be the result of neighbouring worms 'pushing', with no apparent reaction of the individual. (2) Any kind of detect- 
able movement, at normal tape-reading speed, except that of Category 3 (below): parapod movements (undulations), head- or tail-bending, retraction or stretching of body length, forward or backward crawling. (3) Active crawling of the worm (or swimming with no contact with the substratum), i.e. when it moved along a distance exceeding its own length in less than $30 \mathrm{~s}$. (4) Worm outside of camera field: this situation corresponds to a worm that is either at the top of the cages or around the edges (see dark areas in Fig. 1a) and therefore cannot be evaluated, or has escaped the cage (see Fig. 3a,b). If a worm was in the field of the camera but invisible because other individuals were covering it, it was classed as motionless (Category 1), after checking its presence by watching the tape before and after the $30 \mathrm{~s}$ observation period.

Oxygen-level measurements (included in Expt 1). Worms were individually stored in soft polyethylene containers (60 or $150 \mathrm{ml}$ vol.), that were sealed before pressurization. Another seawater container $(60 \mathrm{ml})$ without worms was also pressurised for use as a control. After $6 \mathrm{~h}$, these containers were recovered and oxygen levels determined by the Winkler method (SD of the method $=2 \% ; 95 \%$ CI for $\mathrm{n}=1$ is $\pm 4 \%$ : Aminot \& Chaussepied 1983). The $\mathrm{O}_{2}$ uptake rates were checked against the pressurized control to preclude possible uptake from bacteria in the seawater. The worms were then dried at $80^{\circ} \mathrm{C}(48 \mathrm{~h})$ and weighed (0.1 mg precision).

Electron microscopy (Expts 2 and 4). The heads and tails of the worms were dissected and successively fixed in sodium cacodylate-buffered solutions ( $\mathrm{pH} 7.4$, $\left.4^{\circ} \mathrm{C}\right): 3 \%$ glutaraldehyde $\left(1 \mathrm{~h}\right.$ at $\left.4^{\circ} \mathrm{C}\right)$, followed by $1 \%$ $\mathrm{OsO}_{4}\left(45 \mathrm{~min}\right.$ at $\left.4^{\circ} \mathrm{C}\right)$ and subsequent embedding in Araldite resin. Thin sections were stained with uranyl acetate and lead citrate and observed with a Leo EM 912 Omega electron microscope operating at $120 \mathrm{kV}$. Micrographs were recorded on Kodak SO 163 film.

\section{RESULTS}

\section{In situ video observations}

The video-sequence of Dive 1382, which focused on a group of alvinellid tube openings (Fig. 2), was carefully examined. In this area, we identified at least 7 tube openings, of which 2 were definitely occupied by Alvinella spp. individuals.

Throughout the sequence, 5 Hesiolyra bergi specimens were visible (as many as 4 simultaneously) among the alvinellid tube masses. These worms were frequently observed entering and exiting tubes (6 of the 7 tubes), including those occupied by Alvinella spp. Some alvinellids ejected the worms after a few

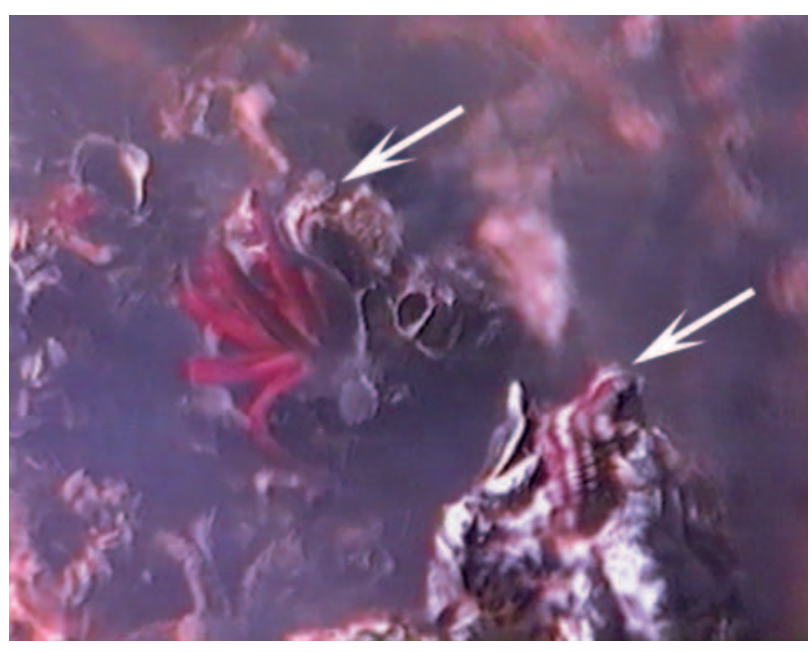

Fig. 2. In situ view of smoker wall at PP 55 marker site $\left(13^{\circ} \mathrm{N}\right.$, EPR), recorded by camera of the submersible 'Nautile'. Some parts of the image appear blurred due to the mixing of warm fluids with cold seawater. Two Hesiolyra bergi specimens are visible (arrows), 1 of them resting above the entrance of an occupied alvinellid tube (the alvinellid has its red branchial tentacles deployed). They are easily identifiable by 2 whitish lateral lines along their body (bacteria associated with their parapods). (Scale: diameter of tube occupied by alvinellid = 1 to $2 \mathrm{~cm}$ )

seconds, but others seemed to tolerate the intruder. $H$. bergi sometimes only partially occupied a tube: 3 individuals disappeared entirely inside the tubes for at least 2 min, whereas another remained for 10 min with about three-quarters of its body length (posterior part) inside the tube. The worms were also observed wandering (over a distance exceeding their body length) over the tube masses. During these wanderings, worms would sometimes rapidly retract the head upon encounter with other organisms (Alvinella spp. small pardaliscid amphipods and also other $H$. bergi specimens). Such 'avoidance' behaviour did not always accompany such encounters. As an alternative to wandering, the worms would remain motionless on the substratum, eventually stretching, retracting, or bending their body away from the other organisms. In the video-sequences, we never observed either actual swimming above the substratum or the uncoordinated behaviour (spasms) witnessed during the heat-exposure experiments.

\section{Control experiments}

Unlike Alvinella spp., Hesiolyra bergi withstood the collection trauma and could be kept in pressurized systems for at least $48 \mathrm{~h}$. In a preliminary experiment (not described here), 2 individuals survived for more than $2 \mathrm{~d}$ at 260 bar, before the experiment was broken off. 
At atmospheric pressure, just after submersible recovery, or when the pressure was released to allow retrieval of some individuals (oxygen uptake experiments), Hesiolyra bergi appeared to be motionless. Only upon careful examination under a dissecting microscope could faint parapod or feeding tentacle movements be detected. However, following re-pressurization, after only a few minutes (sometimes seconds) movements were observed. Detectable movements were parapod undulations, lateral flexion of head or tail, retraction or stretching of body length, forward or backward crawling. Conversely, when pressure was released, the worms seemed to instantaneously lose their ability to move, as evidenced by their apparent paralysis at atmospheric pressure.

At $15^{\circ} \mathrm{C}$, all 15 worms were alive after $18 \mathrm{~h}$ : at this time and at all other times during the experiment, no more than 5 min continuous observation were necessary to detect movements of any individual. Opening of the pressure vessel after $6 \mathrm{~h}$ in order to retrieve some worms, (see 'Materials and methods') obviously had no effect on the mortality of the remaining 15 specimens, since all survived the $18 \mathrm{~h}$ experiment. Throughout the $18 \mathrm{~h}$, however, activity remained relatively low: worms were rarely observed moving more than their own body length within a $30 \mathrm{~s}$ time period (Fig. 3c). Moreover, they remained at the bottom of the cage most of the time, and were never observed swimming.

In the respirometry experiment, oxygen consumption rates correlated well with dry weight (DW) (Fig. 4), to a power of 0.74: (oxygen uptake rate $\left[\mu \mathrm{h}^{-1}\right]$ ) $=$ $2.15 \cdot(\mathrm{DW}[\mathrm{mg}])^{0.74} ; \mathrm{R}=0.982, \mathrm{n}=5, \mathrm{p}=0.003$; i.e., weight-specific oxygen consumption rates for Hesiolyra bergi ranged from 630 to $1130 \mathrm{\mu l} \mathrm{g}^{-1} \mathrm{DW} \mathrm{h}^{-1}$ (mean $\pm \mathrm{SD}=895 \mu \mathrm{h}^{-1} \mathrm{DW} \mathrm{h}^{-1} \pm 190$ ). The oxygen concentration was $245 \pm 10 \mu \mathrm{mol}$ in the control after $6 \mathrm{~h}$, whereas the lowest measured concentration for occupied containers was $137 \pm 6 \mu \mathrm{mol}$, representing more than $50 \%$ of the initial concentration.

\section{Heat-exposure experiments}

Worms submitted to the first heat-exposure experiment (Expt 3: $\max .50^{\circ} \mathrm{C}$ ) were all dead after $18 \mathrm{~h}$. Moreover, they had stopped moving during the fourth hour of the experiment, before the temperature had reached its $50^{\circ} \mathrm{C}$ max., as evidenced by comparison of the relative positions of individuals on all videosequences after that time until the end of the experiment (a slight homogeneous drift [1 to $2 \mathrm{~mm}$ ] occurred for all worms, probably due to ship movement). These worms were also found to be very fragile, breaking apart (almost dissolving) upon retrieval at the end of the experiment. To obtain a more detailed analysis of

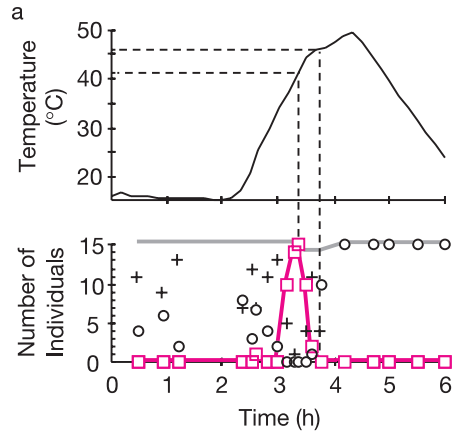

b
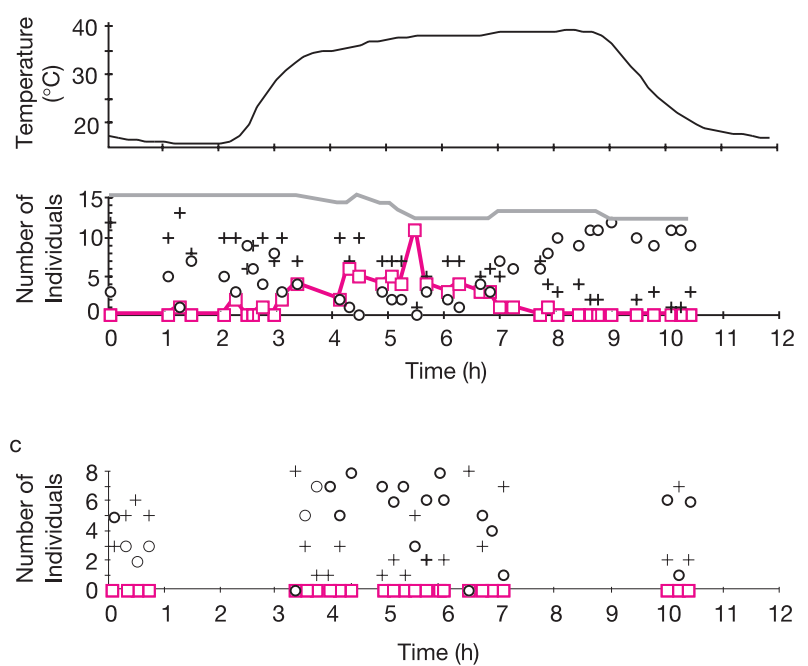

Fig. 3. Hesiolyra bergi. Behaviour during $30 \mathrm{~s}$ sequences, as a function of time since re-pressurization: $0_{1}+$, : : 'motionless', 'moving', and 'active crawling' categories, respectively (see 'Materials and methods'). (a, b) Behaviour (lower graphs) related to temperature (upper graphs, MICREL probe), during 2 heat-exposure experiments (Expts $3 \& 4,15$ individuals each, split into 2 groups of 7 and 8 individuals). Endoscope was moved from one cage to the other (see Fig. 1a), and behavioural data for the last $30 \mathrm{~s}$ in one cage and the first $30 \mathrm{~s}$ in the other cage were pooled; because of possible delay in endoscope adjustments, 1 to 3 min may separate a pair of sequences. For each observation time, the sum of the 3 behavioural categories equals the number of observable worms (grey line, showing that at some point in the experiment some worms were outside the camera field or had escaped, i.e. they belonged to the 4 th category, 'worm outside camera view': see 'Materials and methods'). Maximum heating/cooling rates were 0.44 and $-0.28^{\circ} \mathrm{C} \mathrm{min}{ }^{-1}$, respectively, decreasing when the temperature neared the target-values of the thermoregulating unit. (c) Behaviour of 8 individuals in the same cage at $15^{\circ} \mathrm{C}$ (Expt 1). They were filmed continuously for periods of at least $25 \mathrm{~min}$, at different times of the $18 \mathrm{~h}$ experiment (the last period, 30 min in the 18th hour, is not shown). Within these periods, $30 \mathrm{~s}$ sequences were studied approximately every $3 \mathrm{~min}$ $(\mathrm{SD}=25 \mathrm{~s})$, representing 93 sequences. On the graph, only every fourth sequence is represented (every $12 \mathrm{~min}$ ). Overall, active crawling almost never occurred; it was only observed during 5 sequences out of a total of 93: 1 individual out of 8 $(12.5 \%)$ in 4 sequences; 2 out of $8(25 \%)$ in 1 sequence. Of these 5 sequences, 4 took place during the 18th hour. Mean \pm SD (\%) for 'motionless', 'moving', and 'active crawling' categories are $54.4 \pm 26.2,44.1 \pm 25.1,0.8 \pm 3.6(\mathrm{n}=93)$, respectively 


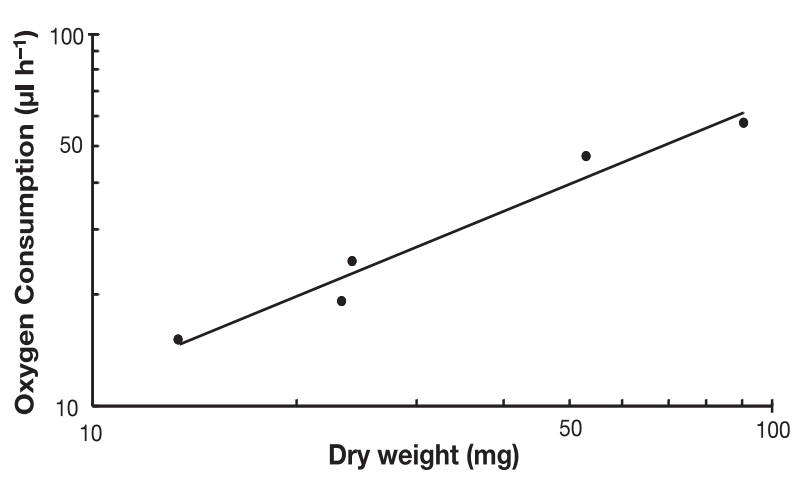

Fig. 4. Hesiolyra bergi. Oxygen uptake as a function of dry weight for 5 individuals maintained for $6 \mathrm{~h}$ at in situ pressure (260 bar), in soft, sealed, polyethylene containers at a temperature of $15^{\circ} \mathrm{C}$ (Expt 1; see 'Materials and methods'). Oxygen consumption rates correlate to dry weight of individuals to a power of 0.74: (oxygen uptake rate $\left.\left[\mu l \mathrm{~h}^{-1}\right]\right)=2.15 \cdot($ dry wt $[\mathrm{mg}])^{0.74} ; \mathrm{R}=0.982, \mathrm{n}=5, \mathrm{p}=0.003$

the influence of temperature, the worms were also observed over several $30 \mathrm{~s}$ video-sequences, throughout the experiment (3 observation categories: 1, motionless; 2, movement [excluding Category 3]; 3, active crawling over distance exceeding worm's own length, see 'Materials and methods'). Fig. 3a,b shows that significant crawling occurred during heat exposure. During these periods, some worms escaped from the visual field (Fig. 1a) and even from the cage itself by crawling or swimming up to the top of the cage. Crawling activity started between 33.5 and $37.5^{\circ} \mathrm{C}$ (Fig. 3a). The peak of this crawling response corresponded to almost $41^{\circ} \mathrm{C}$ (all individuals actively crawling), and was followed by a fast decrease in activity until about $46^{\circ} \mathrm{C}$, accompanied by apparent loss of locomotory coordination (spasms, jerking of entire body, dorsal face resting on the support).

During the second heat-exposure experiment (Expt 4, max. 38 to $39^{\circ} \mathrm{C}$ exposure for $\sim 3.5$ h, Fig. 3b), we observed similar response patterns, including escapes out of the field of view ( 3 individuals) and/or the cage (2 individuals), although not with the same intensity as in Expt 3. Once a temperature of $35^{\circ} \mathrm{C}$ had been reached, and during the following $2 \mathrm{~h}$, at least $20 \%$ of the worms ( 3 individuals) were always actively crawling. After $8 \mathrm{~h}$, no more crawling was observed, although up to 4 worms were still moving at that time. At the end of the $18 \mathrm{~h}$ period, 3 worms were still moving faintly (tail movement), i.e. a survival rate of at least $20 \%$. Later microscopic examination (both light- [not shown] and electron- [Fig. 5b]) revealed that the cuticle of these worms had lifted off the epithelial cells and was severely degraded compared to control individuals (Fig. 5a).
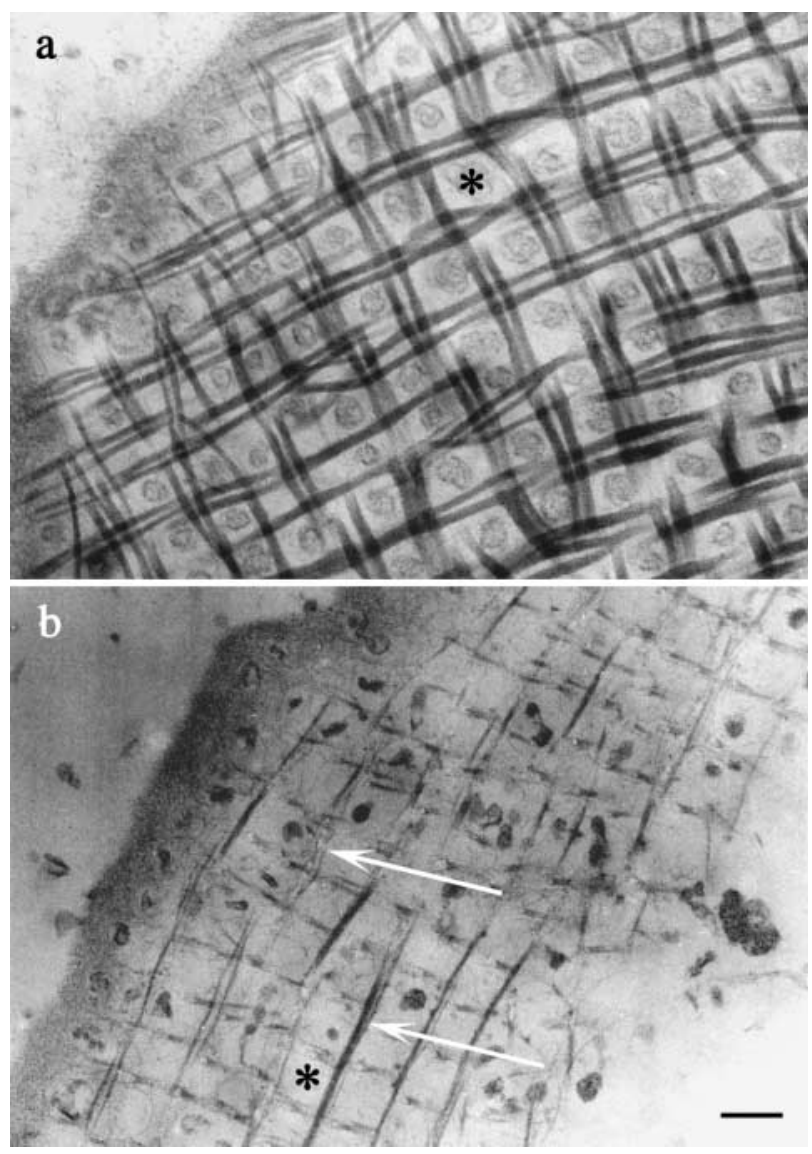

Fig. 5. Hesiolyra bergi. TEM of the cuticle (scale bar $=200 \mathrm{~nm})$. (a) Cuticle fixed upon retrieval from submersible sample container: cuticle is composed of a 2-directional network of collagen fibrils which are parallel to the epithelium; in any given direction, these fibrils form groups of 2 to 3, separated from others by cellular microvilli (*) running perpendicularly through the cuticle. (b) Cuticle fixed after $39^{\circ} \mathrm{C}$ heat-exposure experiment: in many places the cellular extensions have disappeared (*), having either broken or retracted during separation of cuticle and underlying epithelium; remaining collagen fibrils seem to be broken or split into filamentous sub-units (arrowed), and 2-to-3-unit groups are lacking, suggesting melting of many fibrils

\section{DISCUSSION}

One of the first steps of the present study, during the handling of the deep-sea Hesiolyra bergi which experienced collection trauma, was to ensure that repressurized control specimens were in a good state of health. The almost immediate activity of the worms after re-pressurisation, and the $100 \%$ survival rate of the controls over $18 \mathrm{~h}$, with no drastic change in general behaviour, indicate a relatively good physiological state. The oxygen uptake results also confirm this (Fig. 4). First, because of the value of the exponent $(0.74)$, which perfectly fits the classic, almost universal 
uptake/dry-weight relationship expected for annelids (Hemmingsen 1960, Prosser 1973). Second, because these rates are quantitatively in the upper range of values obtained for other polychaete species at $15^{\circ} \mathrm{C}$ : approximately double that obtained for the sedentary coastal annelid Arenicola marina in normoxic conditions (oxygen uptake rate $=1.157[\mathrm{DW}]^{0.73}$ : Toulmond 1975), and similar to that observed for the free-living predator Nephtys hombergi, measured during maximal swimming activity $\left(\sim 1000 \mu \mathrm{lg}^{-1} \mathrm{DW} \mathrm{h}^{-1}\right.$ : Newell \& Norcroft 1967). In view of the fact that $H$. bergi did not crawl actively at $15^{\circ} \mathrm{C}$, our values may appear rather high, possibly reflecting a state of stress induced by the collection process, or resulting from high oxygen levels in our experiments (surface seawater with an $\mathrm{O}_{2}$ concentration of ca $250 \mu \mathrm{mol} \mathrm{l^{-1 }}$ compared to the usual $\mathrm{O}_{2}$ concentration in Pacific deep-sea water of ca $130 \mu \mathrm{mol}$ $1^{-1}$ [Johnson et al. 1986, 1988, Millero 1996], or even lower near deep-sea vents). Considered together, our data nevertheless suggest that the metabolic rate of $H$. bergi was either normal or high under the conditions of our reference experiment. Therefore, our specimens were not moribund as might have been expected after the collection-decompression process.

Another factor requiring discussion is the control experiment, whose conditions cannot be directly compared to those in situ, except for pressure. Temperature records in the habitat of Hesiolyra bergi fluctuate strongly: using a set of 3 autonomous probes, only a few centimetres apart, at the basis of an alvinellid tube assemblage, a $47 \mathrm{~h}$ temperature time-series recorded ranges of 2.3 to $16.3^{\circ} \mathrm{C}$ (Chevaldonné et al. 1991). Other studies have reported discrete submersible measurements from 7 to $91^{\circ} \mathrm{C}$, at the surface of tube masses (Sarradin et al. 1998), with instantaneous temperatures inside the tubes ranging from 40 to $80^{\circ} \mathrm{C}$ (Chevaldonné et al. 1992). Finally, a 2 to $3 \mathrm{~h}$ time-series inside and outside alvinellid tubes (Cary et al. 1998), recorded ranges of $68^{\circ} \mathrm{C} \pm 6.3 \mathrm{SD}$ ), and $22^{\circ} \mathrm{C} \pm 2.5 \mathrm{SD}$, respectively. According to these data, $15^{\circ} \mathrm{C}$ can therefore reasonably be considered as a temperature that would be tolerated by the control specimens. Furthermore, this temperature allows broad comparisons of physiological aspects (such as oxygen uptake, see above).

Extrapolation of experimental behaviour of the worms to natural behaviour should be made cautiously, since both environment and observation conditions differ radically. Moreover, simultaneous observation of more than 2 or 3 individuals in situ was rare, whereas 15 individuals were used in the pressure-vessel experiments. However, the various types of behaviour observed experimentally almost all occurred in natura (within a $30 \mathrm{~s}$ sequence, as for the pressure-vessel experiments: see Fig. 3), except for swimming above the substratum, and uncoordinated jerking (spasms).
The latter behaviours may not be common in situ, or may only occur when Hesiolyra bergi is endangered, or dying, as during heat exposure in our experiments.

In the $50^{\circ} \mathrm{C}$ peak heat-exposure experiment (Expt 3), none of the 15 individuals survived. Of course, survival determination based on recording actual movement may lead to underestimation, since it neglects individuals that are alive but motionless. However, the results at $15^{\circ} \mathrm{C}$ (Expts 1 and 2) show that a few minutes of continuous observation were enough to record all individuals capable of movement. In the case of the $50^{\circ} \mathrm{C}$-exposed worms, the relative positions of all individuals remained identical from the fourth hour of the experiment onwards, i.e. when the temperature had reached $46^{\circ} \mathrm{C}$. Finally, the physical texture of these worms when retrieved from the pressure vessel confirmed that they were all dead. The case was not so clear for $39^{\circ} \mathrm{C}$-exposed worms (Expt 4), and necessitated microscopic examination which revealed cuticular damage (Fig. 5b), showing that long-term survival after this degree of heat exposure would be zero, despite their $20 \%$ survival at $18 \mathrm{~h}$.

Behaviour during heat exposure provides additional information on the response of Hesiolyra bergi to periods of increasing temperature. Fig. 3a,b shows significant active crawling, which in view of the low activity at $15^{\circ} \mathrm{C}$, can be inferred to be an attempt to escape heat. Such behaviour seems to largely occur at vents, since $H$. bergi is frequently seen crawling over chimney walls, where temperature fluctuates strongly. The sharp drop in crawling activity, accompanied by the onset of 'spasms', suggests that the critical thermal maximum of $H$. bergi (defined as a 'thermal trap', i.e. the temperature at which the worm is no longer capable of proper locomotion: Gehring \& Wehner 1995) is most likely to be in the 41 to $46^{\circ} \mathrm{C}$ range. Although the active crawling response was not as general during the $39^{\circ} \mathrm{C}$ heat-exposure (we never observed $100 \%$ of individuals crawling at the same time), nevertheless the response (never $<20 \%$ actively crawling, once the temperature rose above $35^{\circ} \mathrm{C}$ ) also indicated thermal stress: such a high percentage was almost never observed at $15^{\circ} \mathrm{C}$ (see legend to Fig. $3 \mathrm{C}$ ); $35^{\circ} \mathrm{C}$ appears to represent the thermal threshold that triggers the escape response of the worms. Interestingly, this temperature is in the range observed for the onset of crawling in the other experiment (33.5 to $37.5^{\circ} \mathrm{C}$, Expt 3).

The conclusion that can be drawn from these experiments is that Hesiolyra bergi dies within minutes at body temperatures above $40^{\circ} \mathrm{C}$, and does not tolerate sustained body temperatures in the 38 to $39^{\circ} \mathrm{C}$ range. Our data also indicate that $H$. bergi would avoid temperatures exceeding $35^{\circ} \mathrm{C}$. Further investigations are needed to determine the temperature allowing sustained survival of this worm. Also, future research 
should focus on the biochemical heat-shock response of these worms, by characterizing the natural levels of heat-shock proteins and their expression under heatstress conditions. The response of metazoans to thermal stresses is an ongoing research topic, and its interest far exceeds the field of deep-sea hydrothermalism (Feder \& Hofmann 1999). Moreover, it is a key factor to explaining the emergence of life in most extreme environments. Vent creatures and their unique environment may provide new insights into the question of thermotolerance. Simultaneously, the possible influence of collection stress on thermal resistance limits will also have to be investigated. However, for deepsea fauna such an issue is not easy to address and may require tools such as isobaric collection cells. It is already well established that virtually every nonthermal stress (including pressure variations) is capable of inducing synthesis of heat-shock proteins, which in turn could directly influence thermotolerance (Abe et al. 1999, Feder \& Hofmann 1999).

However, the present data do not place Hesiolyra bergi amongst the most thermophilic metazoans, such as Eremogarypus perfectus (Heurtault \& Vannier 1990), a pseudoscorpion that remains unaffected by environmental temperatures exceeding $55^{\circ} \mathrm{C}$. Experiments on live individuals showed that sustained survival temperature for the vent-crab Bythograea thermydron is $<30^{\circ} \mathrm{C}$ (Mickel \& Childress 1982). However, unlike $H$. bergi, this crab is only occasionally observed on hydrothermal chimney walls, and is mainly found within dense tubeworm populations, where temperatures do not exceed 25 to $30^{\circ} \mathrm{C}$ (Desbruyères \& Segonzac 1997, Sarradin et al. 1998). Our results strongly suggest that tolerance to high temperatures is not a pre-requisite to life on a smoker wall. Hesiolyra bergi probably experiences high temperatures in situ, i.e. $>40^{\circ} \mathrm{C}$, but for not more than a few minutes, not long enough for its actual body temperature to rise to that of the environment. Assuming that sustained $\geq 60^{\circ} \mathrm{C}$ temperatures are characteristic for alvinellid tubes (Cary et al. 1998) our conclusions appear paradoxical, since they suggest a rapid death of $H$. bergi inside these tubes. Most probably, the worm simply escapes when it encounters local heat pulses in its environment. For animals such as $H$. bergi, behavioural responses (escape) rather than biochemical adaptations may be sufficient to allow life on deepsea vent chimney walls.

Acknowledgements. We wish to thank the captain and crew of NO 'Atalante', along with technicians and pilots of the submersible 'Nautile', for their assistance throughout this work. We are also grateful to Professor J. Guerdoux, without whose support this work would not have been possible. We also thank C. Bidene and M. Burel for technical help, P. N'Guyen and PAVE-UPMC, for photographic work, and D. R. Dixon for useful advice. This work was supported by CNRS, IFREMER
(URM 7), the French program Dorsales, and the University of Paris (UPMC, UFR 927). Experiments described in this paper complied with the current laws of France.

\section{LITERATURE CITED}

Abe F, Kato C, Horikoshi K (1999) Pressure-regulated metabolism in microorganisms. Trends Microbiol 7:447-453

Aminot A, Chaussepied M (1983) Manuel des analyses chimiques en milieu marin. CNEXO (Centre National pour l'Exploitation des Océans), Brest

Blake JA (1985) Polychaeta from the vicinity of deep-sea geothermal vents in the eastern Pacific I: Euphronisidae, Phylldocidae, Hesionidae, Nereididae, Glyceridae, Dorvilleidae, Orbiniidae, and Maldanidae. Bull Biol Soc Wash 6:67-101

Cary SC, Shank T, Stein J (1998) Worms bask in extreme temperatures. Nature 391:545-546

Chevaldonné P, Desbruyères D, Le Haître M (1991) Timeseries of temperature from three deep-sea hydrothermal vent sites. Deep-Sea Res 38:1417-1430

Chevaldonné $P$, Desbruyères D, Childress JJ (1992) Some like it hot... and some even hotter. Nature 359:593-594

Chevaldonné $P$, Fisher $C R$, Childress JJ, Desbruyères $D$, Jollivet D, Zal F, Toulmond A (2000) Thermotolerance and the 'pompeii worms'. Mar Ecol Prog Ser 208:293-295

Childress JJ, Fisher CR (1992) The biology of hydrothermal vent animals: physiology, biochemistry, and autotrophic symbioses. Oceanogr Mar Biol Annu Rev 30:337-441

Dahlhoff E, Somero G (1991) Pressure and temperature adaptation of cytosolic malate dehydrogenases of shallowand deep-living marine invertebrates: evidence for high body temperatures in hydrothermal vent animals. J Exp Biol 159:473-487

Dahlhoff E, O'Brien J, Somero G, Vetter R (1991) Temperature effects on mitochondria from hydrothermal vent invertebrates: evidence for adaptation to elevated and variable habitat temperatures. Phys Zool 64(6):1490-1508

Desbruyères D, Segonzac M (1997) Handbook of deep-sea hydrothermal vent fauna. IFREMER (Institut Français de Recherche Pour l'Exploitation de la Mer), Brest

Desbruyères D, Crassous $P$, Grassle J, Khripounoff A, Reyss D, Rio M, van Praet M (1982) Données ecologiques sur un nouveau site d'hydrothermalisme actif de la ride du Pacifique Oriental. C R Hebd Séances Acad Sci 295:489-494

Desbruyères D, Gaill F, Laubier L, Fouquet Y (1985) Polychaetous annelids from hydrothermal vent ecosystems: an ecological overview. Bull Biol Soc Wash 6:103-116

Desbruyères $D$, Chevaldonné $P$, Alayse $A M$, Jollivet $D$, Lallier FH, Jouin-Toulmond C, Zal F, Sarradin PM, Cosson R, Caprais JC, Arndt C, O'Brien J, Guezennec J, Hourdez S, Riso R, Gaill F, Laubier L, Toulmond A (1998) Biology and ecology of the 'pompeii worm' (Alvinella pompejana Desbruyères and Laubier), a normal dweller of an extreme deep-sea environment: a synthesis of current knowledge and recent developments. Deep-Sea Res Part II Top Stud Oceanogr 45:383-422

Feder ME, Hofmann GE (1999) Heat-shock proteins, molecular chaperones, and the stress response: evolutionary and ecological physiology. Annu Rev Physiol 61:243-282

Fisher CR (1998) Temperature and sulphide tolerance of hydrothermal vent fauna. Cah Biol Mar 39:283-286

Gaill F, Mann K, Wiedemann H, Engel J, Timpl R (1995) Structural comparison of cuticle and interstitial collagens from annelids living in shallow sea-water and at deep-sea hydrothermal vents. J Mol Biol 246:284-294 
Gehring WJ, Wehner R (1995) Heat shock protein synthesis and thermotolerance in Cataglyphis, an ant from the Sahara desert. Proc Natl Acad Sci USA 92:2994-2998

Hemmingsen AM (1960) Energy metabolism as related to body size and respiratory surfaces, and its evolution. Rep Steno Meml Hosp Nord Insulin-Lab 9:1-110

Heurtault J, Vannier G (1990) Thermorésistance chez deux pseudoscorpions (Garypidae), l'un du désert de Namibie, l'autre de la région de Gênes (Italie). Acta Zool Fenn 190: 165-171

Johnson KS, Beelher CL, Sakamoto-Arnold CM, Childress JJ (1986) In situ measurements of chemical distributions in a deep-sea hydrothermal vent field. Science 231:1139-1141

Johnson KS, Childress JJ, Beehler CL (1988) Short-term temperature variability in the rose garden hydrothermal vent field: an unstable deep-sea environment. Deep-Sea Res 35(10/11):1711-1721

Jollivet D, Desbruyères D, Ladrat C, Laubier L (1995) Evidence for differences in allozyme thermostability in deepsea hydrothermal vent polychaetes Alvinellidae: a possible selection by habitat. Mar Ecol Prog Ser 123:125-136

Juniper SK, Martineu P (1995) Alvinellids and sulfides at hydrothermal vents of the Eastern Pacific: a review. Am Zool 35:174-185

Mickel TJ, Childress JJ (1982) Effects of pressure and temperature on the EKG and heart rate of the hydrothermal

Editorial responsibility: Otto Kinne (Editor),

Oldendorf/Luhe, Germany vent crab Bythogrea thermydron (Brachyura). Biol Bull 162:70-82

Millero FJ (1996) Marine science series: chemical oceanography. Kennish, Lutz, CRC Press, Boca Raton, FL

Newell RC, Norcroft HC (1967) A re-interpretation of the effect of temperature on the metabolism of certain marine invertebrates. J Zool 151:277-298

Prosser CL (1973) Oxygen: respiration and metabolism. In: Prosser CL (ed) Comparative animal physiology. WB Saunders Co, Philadelphia, p 165-211

Quetin LB, Childress JJ (1980) Observations on the swimming activity of two bathypelagic mysid species maintained at high hydrostatic pressures. Deep-Sea Res Part A Oceanogr Res Pap 27:383-391

Sarradin PM, Caprais JC, Briand P, Gaill F, Shillito B, Desbruyères $D$ (1998) Chemical and thermal description of the environment of the genesis hydrothermal vent community (13ํN, EPR). Cah Biol Mar 39:159-167

Somero GN (1992) Biochemical ecology of deep-sea animals. Experientia (Basel) 48:537-543

Toulmond A (1975) Blood oxygen transport and metabolism of the confined lugworm Arenicola marina (L.). J Exp Biol 63:647-660

Wickstrom CE, Castenholz RW (1973) Thermophilic ostracod: aquatic metazoan with the highest known temperature tolerance. Science 181:1063-1064

Submitted: November 24, 2000; Accepted: January 25, 2001 Proofs received from author(s): June 5, 2001 